\title{
Metronidazole Performance as Corrosion Inhibitor for Carbon Steel, 304L Stainless Steel and Aluminum in Hydrochloric Acid Solution
}

\author{
Adriana Samide ${ }^{1, *}$, Petru Ilea ${ }^{2}$, Ana-Cristina Vladu ${ }^{1,2}$ \\ ${ }^{1}$ University of Craiova, Faculty of Sciences, Department of Chemistry, Calea Bucuresti 107i, Craiova, \\ Dolj, Romania \\ ${ }^{2}$ Babes-Bolyai University, Faculty of Chemistry and Chemical Engineering, Arany Janos Street, \\ no. 11, Cluj-Napoca, Romania \\ *E-mail: samide_adriana@yahoo.com
}

doi: $10.20964 / 2017.07 .45$

Received: 21 March 2017 / Accepted: 5 May 2017 / Published: 12 June 2017

\begin{abstract}
The purpose of this paper is to study a possibility of reintroduction in circulation of the expired drugs, as ecological corrosion inhibitors that can have a decisive effect on decreasing of metallic corrosion rate. In this regard, we simultaneously present an overview on metronidazole drug performance, as corrosion inhibitor of three substrates in hydrochloric acid solution. The electrochemical measurements such as potentiodynamic polarization and electrochemical impedance spectroscopy were performed to determine the metronidazole inhibition efficiency that has reached the highest level for aluminum, followed by carbon steel and 304L stainless steel. To discuss the metronidazole action mechanism, UV-Vis spectrophotometry was applied to analyze the uninhibited and inhibited solutions, this showing that in the absence of metronidazole, the solutions were infested with higher amount of metal cations compared to those were inhibited with metronidazole. Corroborating the information, it can affirm that, the protective coatings were formed by overlapping of some processes like pure adsorption of metronidazole and electrostatic interactions for aluminum and, complementary for steels, the adsorption of their complexes with iron, helpful supports being El-Awady kinetic model and Temkin adsorption isotherm, respectively.
\end{abstract}

Keywords: corrosion inhibition; electrochemical measurements; metronidazole; carbon steel; stainless steel; aluminum

\section{$\underline{\text { FULL TEXT }}$}

(C) 2017 The Authors. Published by ESG (www.electrochemsci.org). This article is an open access article distributed under the terms and conditions of the Creative Commons Attribution license (http://creativecommons.org/licenses/by/4.0/). 